\title{
APONTAMENTOS CRÍTICOS PARA UMA HISTÓRIA DO DIREITO PREVIDENCIÁRIO NO OCIDENTE CAPITALISTA
}

\author{
CRITICAL NOTES FOR A HISTORY OF SOCIAL INSURANCE LAW IN WESTERN CAPITALISM
}

Flávio Roberto Batista*

\begin{abstract}
Resumo:
Com o objetivo de compreender criticamente o processo histórico de formação do direito previdenciário, o ensaio o apresenta panoramicamente num contexto geral, debruçando-se mais especificamente sobre aspectos relevantes para desfazer alguns equívocos recorrentes do senso comum sobre o tema, tendo como lastro teórico o materialismo histórico-dialético.

Palavras-chave: História. Direito previdenciário. Crítica. Materialismo históricodialético.
\end{abstract}

\begin{abstract}
:
In order to understand, from a critical way, the process of historical formation of the Social Insurance Law, this essay presents panoramically a general context of this subject and focuses more specifically the relevant aspects to undo some recurring mistakes of common sense on it, with the theoretical support of historical and dialectical materialism.
\end{abstract}

Keywords: History. Social insurance law. Criticism. Historical and dialectical materialism.

\section{Introdução}

Como o próprio nome aponta, o objetivo deste ensaio é a indicação de alguns parâmetros para uma compreensão do processo histórico de formação do direito previdenciário que, a partir de uma perspectiva crítica, ultrapasse o senso comum praticado nas obras dedicadas ao tema.

Cumprir esta tarefa no âmbito do direito é um procedimento arriscado. Aos juristas contemporâneos, de formação demasiadamente específica, faltam elementos básicos de metodologia e conteúdo para desenvolver a tarefa a contento. Ainda assim, parece possível, dentro dos limites que nos são impostos pela formação jurídica, lidar

\footnotetext{
Mestre e Doutor em Direito do Trabalho e da Seguridade Social pela Faculdade de Direito da Universidade de São Paulo. Professor Doutor do Departamento de Direito do Trabalho e da Seguridade Social da Faculdade de Direito da Universidade de São Paulo. Autor da obra Crítica da tecnologia dos direitos sociais e de diversos artigos e participações em obras coletivas. Endereço eletrônico para contato: frbatista@gmail. com.
} 
com esse risco e produzir um relato histórico crítico do direito previdenciário com base em alguns pressupostos que serão lançados a seguir.

Em tempos de domínio do senso comum no mundo jurídico, com a ausência de pensamento crítico que lhe é peculiar, debruçar-se sobre a história defronta o pesquisador com uma miríade de textos que se limita a despejar uma sucessão de fatos aparentemente desconexos, sem qualquer tipo de meditação sobre seu significado ou sua articulação com a realidade social e jurídica.

Nesse sentido, e especificamente no que tange ao direito previdenciário, é comum encontrar descrições de evolução histórica que saltam do mutualismo assistencialista primitivo para as leis alemãs editadas por Bismarck, donde seguem para a Constituição de Weimar, culminando com o Plano Beveridge, o "fim da história" da Seguridade Social em âmbito mundial - releva notar que a história é apresentada sem cerimônias com o adjetivo "mundial", embora restrinja-se à Europa -, não sem antes passar pela doutrina social da Igreja inaugurada com a encíclica Rerum Novarum, do Papa Leão XIII. Igualmente imprecisos são aqueles tratamentos da história que se limitam a descrever a ordem cronológica das normas que regularam a matéria.

É evidente que não podemos deixar de mencionar esses grandes marcos ao tratar da história do direito previdenciário, tendo em vista que os mesmos integram a história, mas sua inserção deve se dar de maneira bastante diversa.

Em artigo curto, mas de grande densidade, lastreado em vasta bibliografia, Arnaldo Moraes Godoy lançou as bases de uma historiografia jurídica aplicada ao direito previdenciário, criticando justamente o senso comum de que falávamos acima. $\mathrm{O}$ trecho é longo, mas vale a transcrição:

Mas se a história parece um guarda-roupa onde todas as fantasias são guardadas, a história do direito lembra a caixa de Pandora de onde saem modelos e institutos de mínima variação semântica, qualificadores de modelo evolucionista, linear, progressista. O presente artigo argumenta que se deve duvidar desse progresso, como já alertara Walter Benjamin na XIII Tese sobre a Filosofia da História. O filósofo da melancolia desconfiava da história que se identifica com o vencedor, da concepção de progresso, da temporalidade, de uma fixação eterna do passado. A história é construção da realidade presente, informada por um salto de tigre que açambarca algo que faz o presente coincidir com a história da humanidade. Deve-se duvidar, pois, da interpretação histórica convencional dos juristas. Essa história oficial do direito, historicista, que toma o passado com uma neutralidade enervante, afina-se com o discurso normativo positivista, também pretensamente neutro, informando a ele, e sendo por ele reverenciada. A crítica a concepções jurídicas positivistas enceta crítica ao historicismo, dada a afinidade 
ideológica e interface conceitual. A história do direito é representada como um fio condutor para realidade normativa perfeita, acabada, realizada. Institutos, conceitos, imagens, perspectivas e acontecimentos prestam-se a justificar a ordem contemporânea. Reservada à parte introdutória dos textos de doutrina, de exegese, de dogmática, a história protagoniza uma ante-sala experimental, indicativa panglossiana de que o mundo caminha para o melhor dos mundos possíveis, concretizado nos excertos legislativos de nossos tempos. Sob a falsa impressão de que dá tônica à interpretação, de que alarga horizontes, de que densifica a argumentação, de que enceta disciplina formativa, de que dá demãos de cultura, a história do direito segue como segundo violino, sonorizando o triunfo de uma racionalidade instrumental que não mais se justifica, e o caos da prática judiciária é prova disso incontestável. ${ }^{1}$

É exatamente disso que falávamos. É imprescindível, a nosso ver, afastar da história da previdência social a perspectiva do vencedor, a história dos grandes estadistas visionários que avançaram décadas na proteção social de seus cidadãos em um curto lapso de tempo. E, como parece óbvio, tal crítica dirige-se justamente à historiografia que fala em "leis de Bismarck" e "plano Beveridge", dentre outros marcos.

Afastar a perspectiva do vencedor, entretanto, também não deve ser procedimento elevado à categoria de dogma, o que poderá tornar míope a análise pelo viés oposto. Embora sejam inegáveis as vantagens dessa outra forma de miopia sobre a primeira, também esta deve ser evitada, na medida do possível. É o que se identifica, a título de exemplo, na seguinte passagem de Aníbal Fernandes:

Tivemos o mutualismo como forma organizatória e como precedente precioso da Previdência Oficial. Sob tal prisma, os festejos oficiais que situam na Lei Elói Chaves (1923) o nascimento da Previdência brasileira têm caráter ideológico que deve ser desvendado: buscam transformar as conquistas sociais, logradas com lutas e a partir das bases, em benesses estatais. $^{2}$

1 GODOY, Arnaldo Moraes. Historiografia jurídica e direito previdenciário. Revista da Procuradoria Federal Especializada do INSS, Brasília, v. 9, n. 3, out.-dez. 2002. p. 73-80. p. 75-76. Disponível em: <http://www. ieprev.com.br/arq/RPFE9302.pdf>.

2 Pedimos vênia para a citação indireta, uma vez que o original é antigo e mimeografado, isto é, não foi editado comercialmente, tendo sido impossível localizá-lo. FERNANDES, Anníbal. Problemas cruciais da previdência social urbana. Mimeografado, 1978, p. 7 apud ALVIM, Ruy Carlos Machado. Uma história crítica da legislação previdenciária brasileira. Revista de Direito do Trabalho, São Paulo, v. 4, n. 18, p. 9-44, março-abril de 1979. p. 13. 
Embora o caso brasileiro não seja o foco do trabalho, convém fazer alguns comentários a respeito. Tem razão o professor Aníbal Fernandes ao afastar a edição da Lei Elói Chaves como o nascimento da previdência social no Brasil. Isso corresponderia à já criticada postura de contar a história sob a perspectiva do vencedor, transformando efetivamente a previdência social em uma concessão de um estadista visionário. Por outro lado, teria sido tal lei uma "conquista social", "lograda com lutas"? Ou seria a Lei Elói Chaves o máximo de que seria possível abrir mão sem prejuízo do capitalismo, em um período de grandes agitações sociais, com crescimento do movimento anarquista e greves longas e organizadas com intensa participação de socialistas?

Adotando-se uma postura histórica dialética e materialista, é preciso entender a história por meio da luta de classes. A partir de tal leitura, são imprestáveis tanto a história do vencedor, que oculta a vinculação dos acontecimentos do mundo jurídico com o substrato na realidade social, quanto a visão romântica do trabalhador organizado que "conquista" seus direitos com "lutas". A despeito disso, repetimos, é preferível o segundo equívoco ao primeiro.

Depois de tais breves considerações acerca da forma de se fazer história do direito previdenciário, outro ponto que chama atenção no texto de Arnaldo Moraes Godoy é o uso que se faz dessa história. Ele critica, como se vê no excerto acima, o uso da história para justificar a ordem jurídica existente como o estágio atual de uma progressão eterna em direção a uma situação sempre melhor, a qual não pode ser evitada.

Tem toda razão o autor nesse ponto, a nosso ver. E sua crítica traz à tona a diferença entre justificar e compreender.

A história não pode, mesmo, ser utilizada para justificar a ordem vigente como etapa necessária de um progresso interminável. Tal concepção exige a pressuposição da existência de uma ordem natural das coisas, de um progresso inevitável em uma direção única, o que, de pronto, retira sua neutralidade e é, por si só, frontalmente contrária ao materialismo histórico e dialético reivindicado algumas linhas acima. A despeito disso, essa é a visão da história que, desde que foi proposta por Auguste Comte, ${ }^{3}$ domina o pensamento científico no mundo das ciências sociais. O pensamento científico positivista ${ }^{4}$

Para mais detalhes sobre o assunto, cf. COMTE, Auguste. Curso de filosofia positiva. 2. ed. São Paulo: Abril Cultural, 1983; ou ainda, para uma visão mais enxuta e didática, cf. LÖWY, Michael. As aventuras de Karl Marx contra o Barão de Münchhausen. Marxismo e positivismo na sociologia do conhecimento. 8. ed. São Paulo: Cortez, 2003.

4 Que, ressalte-se, não coincide com o positivismo jurídico. Naquele, o que está em jogo é uma postura epistemológica, isto é, uma forma de fazer ciência. Neste, ao contrário, trata-se de uma corrente de juristas que definem o direito como direito posto, isto é, que negam a existência jurídica específica a qualquer fenômeno jurídico que não seja decorrente da vontade humana - seja de uma coletividade ou de um único indivíduo com amplos poderes de decisão, como um monarca absoluto - manifestada por determinadas formas prescritas pelo próprio ordenamento jurídico. 
é justamente o que utiliza a perspectiva histórica para justificar a ordem vigente e a sua manutenção.

Como já dito acima, partimos de um entendimento dialético e materialista da história, de modo que os acontecimentos históricos são lidos sempre a partir da luta de classes que, segundo essa concepção, move a história. ${ }^{5}$ Assim, os fatos pretéritos não justificam a situação presente; antes, sua análise ajuda a compreendê-la, como não pode deixar de ser, e fundamenta sua crítica e a sua proposta de superação. ${ }^{6}$

Diante disso, o ensaio propõe-se a fazer uma releitura da historiografia do direito previdenciário, identificando a estrutura que se encontra por trás dos grandes marcos eleitos pela doutrina majoritária, buscando sua compreensão.

\section{A fixação do marco inicial do estudo histórico do direito previdenciário}

Não se pode começar a tratar do tema deste artigo sem a delimitação do período histórico exato que será objeto de nossas ponderações. E isso possui relevância muito maior do que possa parecer a princípio. Com a adequada limitação do espectro histórico, elimina-se o problema apontado por Luciano Oliveira em seu trabalho sobre os erros na pesquisa sociojurídica:

$\mathrm{O}$ que acontece com as habituais incursões históricas que via de regra antecedem a abordagem do tema no presente é, a esse respeito, exemplar. Seguramente a maioria dos trabalhos que tenho examinado não dispensa uma incursão desse tipo, muitas vezes apresentada sob a fórmula "Evolução Histórica do(a)...”, seguindo-se a menção ao objeto que está sendo examinado. É com frequência que, nesse momento, surge a referência a uma antiga e, literalmente falando, mitológica legislação: o famoso Código de Hamurábi! - daí o título deste trabalho.?

Na verdade, a colocação do marco inicial da história em tempos imemoriais, totalmente desconectados do que efetivamente se quer investigar, que foi abordada de passagem na seção anterior, é apenas uma pequena parte do problema identificado por Luciano Oliveira em seu trabalho. Ele condena, como um todo, o sincretismo metodológico

\footnotetext{
5 "A história de todas as sociedades até hoje existentes é a história das lutas de classes". Cf. MARX, Karl; ENGELS, Friedrich. Manifesto comunista. São Paulo: Boitempo, 1998. p. 40.

6 "Os filósofos apenas interpretaram o mundo de diferentes maneiras; porém, o que importa é transformálo" (destaques do original). MARX, Karl. Marx sobre Feuerbach. In: MARX, Karl; ENGELS, Friedrich. $A$ ideologia alemã. São Paulo: Boitempo, 2007. p. 539.

7 OLIVEIRA, Luciano. Não fale do Código de Hamurábi!: a pesquisa sócio-jurídica na pós-graduação em direito. Disponível em: <https://www.uniceub.br/media/180293/Texto_IX.pdf >. Acesso em: 29 abr. 2016. p. 9 .
} 
que se encontra comumente nas pesquisas jurídicas contemporâneas, que pretendem emprestar ao tema de análise um olhar histórico, sociológico ou filosófico, como se tais saberes fossem campos de consenso que pudessem fornecer uma única interpretação dos fatos.

Tal postura, invariavelmente, resulta no que o autor chama no artigo aludido de "reverencialismo", ou seja, a prestação de reverência aos grandes nomes de cada disciplina, repetidos sem qualquer preocupação de obter uma unidade, ou uma sequência relativamente coerente de ideias que efetivamente esteja conectada ao que representam os conjuntos das obras dos aludidos autores. Novamente nas palavras de Luciano Oliveira,

O que normalmente existe, aí, é uma incorporação acrítica dos mais diversos - e às vezes disparatados - autores, como se sociólogos, filósofos, historiadores etc. fossem bens fungíveis numa prateleira de saber universal. ${ }^{8}$

Acerca do sincretismo metodológico e do "reverencialismo", pretendemos já ter estabelecido os pressupostos para evitá-los na introdução. Exatamente por isso é que, guiados pelas reflexões de Arnaldo Moraes Godoy, adotamos o materialismo dialético como modelo de leitura da história. Por outro lado, foi para afastar qualquer forma de "reverencialismo" que pretendemos reler a história geralmente relatada.

O que nos preocupa agora, entretanto, é o cuidado de evitar comparações inapropriadas entre fenômenos atuais e manifestações arcaicas da forma jurídica, o que, de certa forma, guarda ligação com o afastamento da postura evolucionista, criticada por Arnaldo Moraes Godoy. Com efeito, somente este tipo de raciocínio poderia justificar a colocação da previdência social contemporânea e das primeiras manifestações da preocupação humana com a proteção social em uma mesma linha de continuidade, fenômenos esses que, analisados com a devida frieza, não guardam relação alguma.

Somando-se essa preocupação metodológica com a inspiração materialista dialética, chegamos à conclusão de que é incabível buscar antecedentes da previdência social anteriormente à consolidação do Estado Moderno e do capitalismo. Isso porque, sendo a previdência social um conjunto de instrumentos jurídicos cuja utilização é viabilizada principalmente por meio do Estado como ente que assegura direitos, ${ }^{9}$ essa estrutura conceitual é imprescindível à possibilidade de observação do fenômeno, de modo que se torna impensável falar em previdência social anteriormente às primeiras

8 OLIVEIRA, Luciano. Não fale do Código de Hamurábi! ... cit., p. 13. O autor apresenta, nessa passagem, alguns exemplos quase anedóticos dos problemas que aponta, protegendo os autores da ridicularização por meio do anonimato.

9 Conforme disposição específica constante do art. 194 da Constituição Federal, "a Seguridade Social compreende um conjunto integrado de ações de iniciativa dos Poderes Públicos e da sociedade, destinadas a assegurar os direitos relativos à saúde, à previdência e à assistência social". 
iniciativas de modificação na estrutura do Estado Liberal clássico, com a introdução de matizes de intervenção na realidade social.

Dessa forma, devem ser afastadas aquelas notícias históricas de existência de previdência social no Código de Hamurábi, no Talmud, no Código de Manu, na Grécia Antiga, em Roma e na Idade Média. Igualmente, não nos servem aquelas referências feitas a figuras afins, que podem ter inspirado remotamente a previdência social, como o surgimento do contrato de seguro privado, nos negócios marítimos do século XIV. Tampouco as entidades caritativas religiosas que mantinham as Santas Casas de Misericórdia e instituições congêneres. Nada disso pode ser objeto de nosso estudo, para manter a coerência com as premissas anteriormente lançadas.

Embora amparados em outros pressupostos teóricos, também Marcus Orione Gonçalves Correia e Érica Paula Barcha Correia haviam considerado disparatadas tais remissões ancestrais:

No entanto, embora estejamos diante de uma medida, dentre várias outras, de proteção social - ainda que contemplada apenas determinada categoria de pessoas -, não se pode dizer que, na Roma do Império, tenham sido fincadas as bases da Seguridade Social moderna. ${ }^{10}$

Nossa trajetória, portanto, começa com o surgimento dos direitos sociais, entendidos como prestações dos poderes públicos destinadas a garantir proteção social aos cidadãos, na forma como os conhecemos hoje. Para contextualizar este marco inicial, traçaremos algumas breves linhas a respeito da conjuntura que levou ao surgimento dos direitos sociais. ${ }^{11}$ Como não possuímos pretensões de pesquisa historiográfica, basta que a exposição seja feita em linhas gerais, sem minúcias de datas e pesquisas acuradas acerca de todos os fatores envolvidos, até em função da precedência estrutural econômica implícita ao materialismo dialético por nós adotado. Voltemos nossas atenções, dessa forma, às modificações por que passou o mundo ocidental, particularmente a Europa e os Estados Unidos da América, no século XIX, e os antecedentes históricos que levaram a tais modificações, necessários à sua contextualização.

3. Antecedentes históricos do processo capitalista

Desde o final do século XIV e o início do século XV, o feudalismo dava sinais de que sua sobrevida não seria muito longa. O renascimento do comércio havia dado

10 CORREIA, Marcus Orione Gonçalves; CORREIA, Érica Paula Barcha. Curso de direito da seguridade social. 2. ed. São Paulo: Editora Saraiva, 2002. p. 2.

11 A exposição será livremente baseada em HUBERMAN, Leo. História da riqueza do homem. 21. ed. rev. Rio de Janeiro: Editora Guanabara, 1986. Trechos específicos da obra serão referidos quando for conveniente. 
ensejo à formação de cidades, cada vez maiores e em maior número, nos cruzamentos de rotas comerciais e em locais portuários, exercendo grande atração sobre a população camponesa e tornando, pouco a pouco, cada vez mais inviável o modo de produção servil.

\begin{abstract}
À medida que o comércio continuava a se expandir, surgiam cidades nos locais em que duas estradas se encontravam, ou na embocadura de um rio, ou ainda onde a terra apresentava um declive adequado. Tais eram os lugares que os mercadores procuravam. (...). O povo começou a deixar suas velhas cidades feudais para iniciar vida nova nessas ativas cidades em progresso. A expansão do comércio significava trabalho para maior número de pessoas e estas afluíam à cidade, a fim de obtê-lo. ${ }^{12}$
\end{abstract}

Paralelamente, a reforma protestante destruiu a hegemonia católica no plano valorativo da sociedade, substituindo a ética da caridade e do amor incondicional ao próximo pela ética do trabalho e da fé individual, o que deu subsídios morais para o desenvolvimento cada vez maior do comércio, outrora condenado como prática usurária, e então louvado como forma digna de trabalho, que poderia levar à salvação.

Mas o mais importante é que o trabalho constitui, antes de mais nada, a própria finalidade da vida. A expressão paulina: "Quem não trabalha não deve comer" é incondicionalmente válida para todos. A falta de vontade de trabalhar é um sintoma da ausência do estado de graça. ${ }^{13}$

A riqueza, dessa forma, é condenável eticamente, só na medida em que constituir uma tentação para a vadiagem e para o aproveitamento pecaminoso da vida. Sua aquisição é má somente quando é feita com o propósito de uma vida posterior mais feliz e sem preocupações. Mas, como o empreendimento de um dever vocacional, ela não é apenas moralmente permissível como diretamente recomendada. ${ }^{14}$

Os ensinamentos protestantes foram de suma importância no que diz respeito à criação das condições para a acumulação primitiva de capital, que permitiu, por sua vez, o surgimento do capitalismo.

Que qualidades poderiam ser mais propícias a um sistema econômico - no qual a acumulação de riqueza, de um lado, e os firmes hábitos de trabalho, por outro, constituíam as pedras fundamentais - do que esses mesmos ideais religiosos transformados em prática cotidiana pelos adeptos

\footnotetext{
12 HUBERMAN, Leo. História da riqueza do homem ... cit., p. 26-27.

13 WEBER, Max. A ética protestante e o espírito do capitalismo. In: WEBER, Max. Textos selecionados. São Paulo: Abril Cultural, 1980. p. 210.

14 WEBER, Max. A ética protestante e o espírito do capitalismo ... cit., p. 214.
} 
de Calvino? Era melhor cristão o homem cujas atividades fossem mais adequadas à aquisição de fortuna - ao espírito do capitalismo. Uma união perfeita. ${ }^{15}$

Leo Huberman, a esse respeito, sustenta que até mesmo antes da reforma protestante já havia uma tendência de flexibilização das normas religiosas e legais acerca da usura e do comércio com lucro:
É fácil ver que a doutrina do pecado da usura iria limitar os processos do novo grupo de comerciantes que desejava negociar numa Europa em expansão comercial. Tornou-se na verdade um obstáculo quando o dinheiro começou a ter um papel cada vez mais importante na vida econômica.
(...).
Que aconteceu então, quando a doutrina da Igreja, destinada a uma economia antiga, chocou-se com a força histórica representada pelo aparecimento da classe de comerciantes? Foi a doutrina que cedeu. Não de uma vez só, evidentemente. Lentamente, centímetro por centímetro, nas novas leis que diziam: "A usura é um pecado - mas, sob certas circunstâncias...", ou então: "Embora seja pecado exercer a usura, não obstante, em casos especiais...". ${ }^{16}$

A evolução de tais processos nas cidades da época, chamadas de burgos, desencadeou o processo de dissolução da antiga divisão de classes da sociedade medieval - senhores feudais e servos - para substituição pela divisão capitalista de classes. Surgia ali o burguês, homem livre que, praticando o comércio nas cidades e feiras, começou a acumular capital. O fenômeno foi chamado por Marx de acumulação primitiva de capital, ou capitalismo mercantil. Ao final dessa fase, com o início do capitalismo propriamente dito, em sua fase industrial, o capital acumulado fez do burguês dono dos meios de produção, com os quais exploraria a força de trabalho do proletariado, composto em sua maioria de servos egressos dos feudos onde não havia mais trabalho suficiente ou que haviam sido expulsos de sua vida agropastoril por processos violentos comumente denominados de cercamentos.

O progressivo aumento do poder econômico da burguesia emergente e declínio do poder dos senhores feudais levaram à formação de uma aliança entre os burgueses e os reis - os quais, à época, não passavam de senhores feudais especialmente poderosos e proprietários de maiores extensões de terras - para a consolidação dos Estados-nação e das monarquias nacionais. ${ }^{17} \mathrm{O}$ processo, que culminou com o tratado

\footnotetext{
15 HUBERMAN, Leo. História da riqueza do homem ... cit., p. 169.

16 Id. Ibid., p. 40.

17 Dada a formulação excessivamente simplista do fenômeno, convém fazer um alerta aos riscos da leitura voluntarista da história, que, evidentemente, não foi o que se pretendeu fazer aqui. Em outras palavras, é
} 
conhecido como Paz da Westfália, firmado em 1654, no qual foi definido o embrião da divisão territorial e política da Europa continental contemporânea, ensejou o pleno desenvolvimento da política mercantilista e da expansão colonial, faceta do mercantilismo pela qual as monarquias lançaram-se em uma corrida pela conquista de colônias em terras no além-mar, principalmente na América e na África. As colônias foram fundamentais na prosperidade do mercantilismo, na medida em que ajudavam na manutenção da balança comercial e forneciam a maior parte dos metais preciosos para a formação dos tesouros reais.

Na Idade Média, a autoridade do rei existia teoricamente, mas de fato era fraca. Os grandes barões feudais eram praticamente independentes. Seu poderio tinha de ser controlado, e realmente o foi.

(...).

O rei fora um aliado forte das cidades na luta contra os senhores. Tudo o que reduzisse a força dos barões fortalecia o poder real. Em recompensa pela sua ajuda, os cidadãos estavam prontos a auxiliá-lo com empréstimos em dinheiro. (...).

$\mathrm{O}$ rei foi grato aos grupos comerciais e industriais que lhe possibilitaram contratar e pagar um exército permanente, bem equipado com as últimas armas. ${ }^{18}$

A política mercantilista das monarquias nacionais representou a salvação da nobreza, que manteve em grande medida seu modo de vida, ao menos enquanto a burguesia manteve-se satisfeita em continuar apenas acumulando riquezas, mesmo alijada do poder político.

Era por estarem sempre em dificuldades monetárias que os governos davam tamanha importância ao amontoamento de metais preciosos. E como acreditavam também que o tesouro podia ser obtido pelo comércio, era natural considerarem os interesses do Estado e da classe de mercadores ou comerciantes como idênticos. Foi assim que o Estado tomou como sua tarefa principal o apoio e estímulo ao comércio e a tudo que se relacionasse com ele.

Foi pelo comércio que o Estado se tornou grande, e conseguiu sua cota na expansão dos negócios e territórios. O mercantilismo era o regime dos mercadores. ${ }^{19}$

\footnotetext{
óbvio que não houve uma reunião de negociação entre o rei e um representante dos burgueses para formular conscientemente as bases da monarquia nacional. A despeito disso, a alegoria da aliança entre tais figuras é didaticamente útil e seu uso, para os estreitos fins a que se destina neste trabalho, não causa prejuízos.

18 HUBERMAN, Leo. História da riqueza do homem ... cit., p. 71-72.

19 HUBERMAN, Leo. História da riqueza do homem ... cit., p. 130.
} 
Nessa altura, as cidades não viviam apenas do comércio de produtos agrícolas. Desenvolviam-se as manufaturas, unidades de produção protoindustriais organizadas em torno de entidades denominadas corporações de ofício. As corporações possuíam a dupla intenção de formar novos artífices e fazer reserva de mercado, com o perdão do anacronismo, em favor dos artesãos que praticavam a manufatura em cada localidade.

Esse modo de vida que substituiu o feudalismo durante a era moderna passou, mais tarde, sob o nome de Antigo Regime, a ser combatido pela burguesia, a qual pretendia aliar ao seu poder econômico também o poder político, eliminando as amarras impostas ao comércio e à manufatura e deixando de sustentar os luxos da nobreza parasitária. Nesse contexto, nos séculos XVII e XVIII, a Europa foi sacudida por revoluções liberais burguesas, inspiradas em uma densa produção filosófica que continua sendo aprimorada até os dias de hoje. Tais revoluções substituíram o Antigo Regime por governos, em linhas gerais, democráticos e liberais. A primeira delas ocorreu na Inglaterra, no início do século XVII, sendo que a última revolução burguesa dessa fase foi a Revolução Francesa, para a qual se adotou o ano de 1789 como marco, mas que foi um processo muito mais longo. ${ }^{20}$

Com o novo cenário político e estando em estágio avançado a acumulação primitiva de capital, estavam criadas as condições para o fenômeno que desencadearia a série de acontecimentos que nos importa para o estudo da história da previdência social: o processo, iniciado também na Inglaterra e mais tarde espalhado pelo resto da Europa, conhecido por Revolução Industrial.

4. O surgimento e a evolução do capitalismo liberal e os questionamentos à ordem instituída

A Revolução Industrial marcou a passagem do protocapitalismo comercial para o capitalismo industrial. Invenções tecnológicas permitiram a mecanização da agricultura e da produção, diminuindo a necessidade de força de trabalho humana. Com isso, os trabalhadores perderam o controle do processo de produção, o qual, bem ou mal, estava em seu poder na manufatura organizada em torno das corporações de ofício. Isso mudou radicalmente a relação entre capital e trabalho. O burguês, rico, tornou-se o único

\footnotetext{
20 É evidente que houve avanços e retrocessos em tais processos revolucionários, e as democracias liberais não foram, desde o início, completamente estáveis. Tome-se como exemplo a França, em que, depois da Revolução de 1789, houve inclusive uma restauração monárquica, por parte de Napoleão. As posturas dos governos e a regulamentação jurídica da economia, entretanto, a despeito da forma de Estado e de governo, demonstravam uma modificação profunda em relação ao Antigo Regime, e isso é o que verdadeiramente importa para nossos fins.
} 
proprietário dos meios de produção, pois podia investir nas inovações tecnológicas. O trabalhador, agora chamado de proletário, substituído no campo e na cidade por máquinas, tinha somente a sua força de trabalho, que passou a negociar com o burguês para poder sobreviver.

Era o liberalismo que dava a sustentação política e jurídica para essa situação. A teoria segundo a qual todos os sujeitos são livres e iguais perante a lei, estando, destarte, aptos a negociar segundo a autonomia de suas vontades, sustentava uma ordem em que o trabalhador, porque queria, vendia sua força de trabalho ao capitalista por preços fixados livremente segundo as regras de mercado, as leis de oferta e procura.

Significativa, a esse respeito, a seguinte passagem, constante de um texto da época em que se comentava a primeira lei inglesa de limitação da jornada de trabalho:

Constituirá realmente uma surpresa para todos os espíritos desapaixonados que 93 membros da Câmara dos Comuns pudessem ser capazes de determinar que nenhuma classe de artesãos adultos trabalhe mais de 10 horas por dia - uma interferência na liberdade dos súditos, que nenhuma outra legislação na cristandade teria tolerado por um momento. Os industriais de Gloucester caracterizaram, com justiça, essa proposta como digna da pior Idade Média. ${ }^{21}$

Ora, com um enorme contingente de desocupados prontos a aceitar qualquer trabalho mediante qualquer pagamento, os salários pagos eram, inevitavelmente, baixíssimos e insuficientes para a subsistência dos trabalhadores. Isso permitia o perfeito funcionamento do mecanismo que se encontra no âmago do capitalismo industrial: o mais-valor. ${ }^{22}$

Os trabalhadores, por sua vez, encontravam-se em situação de penúria cada vez maior. A autonomia da vontade permitia que eles vendessem sua força de trabalho por até vinte horas diárias, bem como que o trabalho fosse feito por mulheres, inclusive as grávidas - eram comuns os partos dentro da fábrica, durante o horário de trabalho -, e crianças, mesmo as muito pequenas. Com péssimas condições de alimentação e descanso, baixa especialização, e o problema do emprego de pessoas sem a mínima condição de trabalho, como os doentes e as crianças pequenas, a quantidade de acidentes fatais e mutilantes era muito alta, agravando ainda mais o cenário.

${ }_{21}$ URE, Andrew. The philosophy of manufactures. Londres, 1861, p. 17 apud HUBERMAN, Leo. História da riqueza do homem ... cit., p. 184.

22 O processo de extração do mais-valor, evidentemente, não pode ser explorado nos estreitos limites deste ensaio e não pode ser integralmente apreendido senão em sua fonte: MARX, Karl. O capital. São Paulo: Boitempo, 2014. v. 1. 
A primeira reação contra essa situação foi visceral e quase instintiva: a destruição das máquinas que impunham o ritmo acelerado de trabalho e, substituindo o homem, obrigavam os trabalhadores a se sujeitaram às péssimas condições de trabalho, diante da grande concorrência. Não se sabe ao certo como se deu o início de tal processo de destruição de máquinas, até em função de seu provável início espontâneo, em momentos de grande tensão dos trabalhadores. $\mathrm{O}$ fato é que, mais tarde, o movimento de destruição de máquinas ganhou organização ${ }^{23}$ e até um nome, Ludismo, em referência a Edward "Ned" Ludd, seu líder.

O movimento ludista, como não poderia deixar de ser, encerrou-se com a prisão e o enforcamento de seus principais líderes. A repressão ao ludismo foi, além de violenta, rápida. Já em 1812 foi aprovada pelo parlamento inglês "uma lei tornando passível de pena de morte a destruição de máquinas". ${ }^{24}$

Com efeito, não poderiam os trabalhadores manifestar sua reação de maneira tão caótica, tendo em vista que seu inimigo tinha a seu lado a poderosa máquina de repressão do Estado. É que o Estado Liberal existente à época tinha por único escopo a garantia jurídica da propriedade e da liberdade individuais, possuindo uma estrutura restrita à repressão de qualquer tentativa de supressão de tais direitos.

Destruir máquinas não era um plano bom. Mesmo que tivesse êxito, não teria resolvido os problemas dos trabalhadores. Investiam contra um objetivo errado. A máquina não era a causa de seus males - mas sim o dono dela que, embora sem a mesma ostensividade do latifundiário que fechava sua terra, mas com igual eficiência, os estava afastando dos meios de produção.

Os trabalhadores verificaram logo que a destruição das máquinas não era a solução. Tentaram outros métodos. Eis, por exemplo, a petição de um grupo humilde, que se assinava "Tecelões Pobres".

(...).

Houve outras petições. Centenas delas. Petições enviadas não aos patrões - isso foi logo abandonado como inútil -

23 Com efeito, um exame das notícias da época mostra que os ataques às máquinas passaram a ser muito organizados, inclusive com aparente planejamento antes da execução. Confira-se, a respeito, tradução livre de notícia de jornal publicada em Nottingham, em 25 de janeiro de 1812: "Visto que, na última quinta-feira à noite, cerca de dez horas, um grande número de homens, armados com pistolas, martelos e paus, entraram na residência de George Bell (...), disfarçados com máscaras sobre as faces, (...) e depois de baterem no dito George Bell, eles deliberadamente quebraram e destruíram cinco teares (...), todos os quais trabalhando em força máxima; dá-se notícia de que, se alguma pessoa der informações do ofensor ou de qualquer um que entrou na residência, receberá recompensa de 200 libras". Um fac-símile do recorte encontra-se disponível em: <http://www.nationalarchives.gov.uk/pathways/localhistory/gallery3/images/luddism1.jpg>. Acesso em: 20 out. 2007.

24 HUBERMAN, Leo. História da riqueza do homem ... cit., p. 186. 
mas ao Parlamento. Muitas foram postas de lado, mas outras receberam certa atenção. ${ }^{25}$

Com o fim do movimento ludista, os trabalhadores passaram a manifestar sua resistência de formas, por assim dizer, mais racionais e organizadas, como o movimento cartista $^{26}$ e o sindicalismo, ${ }^{27}$ surgido também na Inglaterra com as trade unions. Dizse de tais movimentos que alcançaram conquistas importantes em termos de direitos dos trabalhadores. É que tais movimentos possuíam, muitas vezes, cunho socialista e comunista, cuja elaboração teórica havia começado aproximadamente na mesma época, com os pioneiros Condorcet, Saint Simon e Fourier, representantes da chamada fase do socialismo utópico.

Embora não seja possível determinar exatamente a força de que gozavam as ideias comunistas à época, podemos extrair algumas conclusões acerca do próprio

25 Id. Ibid. p. 186-187.

26 O movimento cartista defendia, principalmente, uma maior democratização política, em torno de um documento intitulado Carta do Povo, que reivindicava, basicamente, o sufrágio universal masculino e a criação de maiores possibilidades de exercício de mandatos pelos pobres. O movimento partia da opinião extremamente otimista de que, com acesso ao voto e, portanto, presumidamente com acesso ao poder, seria possível aos trabalhadores providenciar por conta própria a melhoria de suas condições de vida. A história mostrou que eles estavam enganados, principalmente porque, quando as reivindicações do cartismo foram atendidas, o movimento já estava integralmente cooptado pelas forças liberais. Confira-se, a respeito, interessantíssima passagem de Engels, em tradução livre: "O cartismo agonizava. A nova prosperidade industrial, lógica e quase natural depois do término da crise de 1847, foi atribuída exclusivamente ao influxo do livre comércio. Em virtude destes dois fatos, a classe operária inglesa converteu-se publicamente em apêndice do 'grande' Partido Liberal, dirigido pelos fabricantes. (...). A violenta oposição dos cartistas, não contra o livre comércio, mas contra sua conversão na única questão vital do país, fez compreender aos fabricantes - e cada dia que passava se o fazia compreender melhor - que sem a ajuda da classe operária a burguesia não logrará jamais estabelecer plenamente seu domínio social e político sobre a nação. (...). E a Carta do Povo, antes tão execrável, converteu-se no principal programa político destes mesmos fabricantes que até há pouco a tinham combatido". ENGELS, Friedrich. Prefacio a la situación de la clase obrera en Inglaterra. In: MARX, Karl; ENGELS, Friedrich. Obras escogidas. Moscou: Editorial Progreso, 1955. t. 2. p. 412 .

27 "O sindicato não era novidade. Foi uma das mais antigas formas de organização dos trabalhadores, evoluindo naturalmente das antigas associações de jornaleiros. Quando, porém, a importância do capital na indústria tornou-se tão grande, as associações de trabalhadores modificaram seu caráter, passando do tipo de corporação para o do sindicato de hoje, ou seja, um corpo de trabalhadores de um determinado ramo organizado com o objetivo de conseguir melhores condições de defender seus interesses, de depender apenas de si mesmos". HUBERMAN, Leo. História da riqueza do homem ... cit., p. 189. É interessante observar que também os sindicatos, com o passar do tempo, tiveram algumas de suas reivindicações atendidas e foram cooptados, como forma de evitar a luta armada. Novamente citando Engels, em tradução livre: "Os sindicatos, considerados até há pouco obra do diabo, eram mimados e protegidos pelos industriais como instituições perfeitamente legítimas e como meio eficaz para difundir entre os operários doutrinas econômicas saudáveis. Chegou-se inclusive à conclusão de que as greves, reprimidas até 1848, podiam ser em certas ocasiões muito úteis, sobretudo quando eram provocadas pelos senhores fabricantes no momento em que eles consideravam oportuno". ENGELS, Friedrich. Prefacio a la situación de la clase obrera en Inglaterra ... cit. p. 412. 
Manifesto do Partido Comunista, de 1848, que é aberto com a sugestiva frase, já imortalizada, segundo a qual "um espectro ronda a Europa - o espectro do comunismo". ${ }^{28}$

Ora, para que assim se tenham referido Marx e Engels ao redigir o Manifesto, é de se supor que havia um forte movimento nesse sentido em diversos pontos da Europa, o que, evidentemente, ameaçava a permanência pacífica do capitalismo, até em função de exortações à revolução e à luta armada, como a que fecha o próprio Manifesto referido: "Proletários de todos os países, uni-vos!". ${ }^{29}$

Foi por essa razão que, paulatinamente, o capitalismo e o liberalismo começaram a ceder espaço às reivindicações dos trabalhadores, dando origem às primeiras manifestações de legislação social. Estas, nos albores da proteção social, preocupavamse, inicialmente, com questões como a duração da jornada de trabalho e suas condições. Com os trabalhadores ainda pouco organizados, entretanto, bastavam poucas medidas, que sequer arranhavam o liberalismo selvagem, para eliminar as incipientes tensões sociais e manter a ordem a salvo do "espectro" comunista. Assim, embora seja nesse período que se encontram as primeiras manifestações concretas de legislação social, não houve ainda muitos avanços. Implantavam-se as medidas necessárias para impedir a luta operária armada, que assombrava os espíritos burgueses e liberais desde a fase do Terror da Revolução Francesa.

O processo de Revolução Industrial continuou no mesmo ritmo por várias décadas, com o progressivo aumento da velocidade do surgimento de inovações tecnológicas, como a substituição do vapor pela eletricidade no final do século XIX e o aumento da mecanização da produção e, consequentemente, da especialização do trabalhador, que passa a ser um mero operador de máquinas, com funções cada vez mais específicas.

\section{As primeiras manifestações de legislação social}

É nesse contexto que se encontra o aclamado marco inicial da Seguridade Social no mundo: as leis de seguro social alemãs, de Otto von Bismarck, sendo a primeira delas em 1883. A Alemanha, como se sabe, estava atrasada, por assim dizer, no processo acima descrito. Sua unificação como Estado nacional deu-se somente em 1870, no contexto da guerra franco-prussiana, sob o comando de Guilherme I, rei da Prússia, que tinha em Bismarck seu chanceler.

Nesse período, já estava avançado o estabelecimento do liberalismo em outras regiões da Europa, notadamente a Inglaterra e a França. Até em função disso, a

$28 \quad$ MARX, Karl; ENGELS, Friedrich. Manifesto comunista. São Paulo: Boitempo, 1998. p. 39.

29 Id. Ibid., p. 69. 
Alemanha não participou do processo de colonização ocorrido nos séculos precedentes; sua indústria nacional era quase inexistente e a população rural era muito maior que a urbana, esta restrita a poucas regiões, o que não ocorria na Inglaterra desde 1850, quando a população urbana ultrapassou a rural em número.

Vê-se, portanto, que a legislação previdenciária alemã teve pouca ou nenhuma expressão, já que seu alcance era extremamente reduzido. É sintomático, nesse sentido, que tenha sido a Alemanha o primeiro país a adotar tal espécie de legislação. Seu conturbado processo de unificação, ainda em curso naquele momento, demandava que a ditadura de Bismarck adotasse posturas demagógicas, que não poderiam, por outro lado, afetar muitos interesses.

A estratégia foi extremamente bem-sucedida. Max Weber, sociólogo que viveu à época e pôde observar as vicissitudes do processo de unificação política de seu país, manifestou-se acerca do governo de Bismarck:

A atual condição de nossa vida parlamentar é um legado da longa dominação do príncipe Bismarck e da atitude da nação para com ele desde a última década de seu cargo de chanceler. Esta atitude não tem paralelo na reação de qualquer outro grande povo com respeito a um estadista de tal envergadura. Em nenhuma outra parte do mundo, mesmo a mais desenfreada adulação de um político conseguiu fazer uma nação orgulhosa sacrificar suas convicções essenciais tão completamente. ${ }^{30}$

O que se percebe é que a edição das leis previdenciárias de Bismarck fazia parte de todo um contexto de uma espécie de populismo primitivo, que utilizava o ufanismo desencadeado pela vitória na guerra, o carisma pessoal do kaiser e de seu chanceler e a violência como formas de manter a unidade do país que acabava de se formar, sem descuidar da continuidade das formas de dominação econômica. Isso se torna ainda mais evidente quando se recorda que o movimento de unificação era sustentado por uma aliança entre a alta burguesia, que tentava já havia vários anos promover um processo de modernização do país, com a alta aristocracia rural, os chamados junkers, classe de que Bismarck era egresso.

Estabeleceu-se uma aliança política entre a alta burguesia e os Junkers, aristocracia prussiana que controlava a administração e o exército, e promoveu-se a modernização militar, liderada pelo general Von Moltke, que se transformaria no principal instrumento da unificação alemã.

30 WEBER, Max. Parlamentarismo e governo numa Alemanha reconstruída. In: WEBER, Max. Textos selecionados. São Paulo: Abril Cultural, 1980. p. 7. 
Esse processo de fortalecimento da Prússia culminou em 1862 com a nomeação de Otto Von Bismarck, representante da aristocracia Junker, para o cargo de chanceler da Prússia. ${ }^{31}$

Ainda a respeito das leis de Bismarck, é curioso notar que a proteção, em termos de previdência social, tenha sido iniciada pelos benefícios oriundos de incapacidade. Em tempos de condições tão ruins de vida, não havia muitos trabalhadores operários que chegassem à velhice para que fosse prioritário pensar em aposentadorias. Igualmente, somente tinham forças para reivindicações aqueles trabalhadores que, estando alguma vez empregados, deixavam tal condição por terem sofrido acidentes no trabalho ou sido acometidos por doenças. A grande massa de mendigos e desocupados que rondava as cidades à época não constituía preocupação real, inclusive porque tinham sido alijados até mesmo da degradante condição de proletário, reservada somente a uma parte dos que não detinham a propriedade dos meios de produção.

Outro fato que chama nossa atenção refere-se a uma situação intrigante. Como temos afirmado até então, a vanguarda dos movimentos econômicos e políticos, desde os primórdios da afirmação do capitalismo, esteve vinculada à Inglaterra e, em menor medida, à França. Nesses países, como também já foi dito, houve avanços paulatinos e graduais em direção à proteção de direitos dos trabalhadores. Haveria de existir um motivo para que as mudanças sociais ocorressem gradualmente nos países da vanguarda industrial e política e aos solavancos na Alemanha. Esse motivo era justamente a predominância da população rural e a pouca importância da questão operária, que permitia o uso demagógico de medidas como as leis previdenciárias. Assim como em diversos outros campos, a Alemanha limitava-se a pensar os acontecimentos passados em outros países, porque sua própria situação de estagnação e atraso a impedia de processar sua filosofia desenvolvida na realidade, ou então a obrigava a fazê-lo de maneira a causar impactos mínimos na realidade. Anos antes, Marx fazia afirmação semelhante acerca do processo intelectual e político alemão:

Por conseguinte, na Alemanha começa-se com aquilo que já terminou na França e na Inglaterra. A ordem antiga e podre, contra a qual estas nações se revoltam teoricamente e que apenas suportam como cadeias, é saudada na Alemanha como aurora de um futuro glorioso que, até agora, a custo ousa mover-se de uma teoria astuta para uma prática implacável.

(...).

31 MELlO, Leonel Itaussu Almeida; COSTA, Luís César Amad. História moderna e contemporânea. 5. ed. São Paulo: Scipione, 1999, p. 244. 
Em política, os alemães pensaram o que as outras nações fizeram. (destaques do original) ${ }^{32}$

A forma pela qual se deu o processo de unificação alemã foi um dos fatores que acabou desencadeando a eclosão, anos mais tarde, da Primeira Guerra Mundial. Primeiramente, as punições aos vencidos na guerra franco-prussiana e as perdas territoriais aí envolvidas deram origem a um revanchismo por parte dos franceses que influiu muito no sistema de alianças que precedeu ao conflito e que, até hoje, depois de dois conflitos mundiais em lados opostos, ainda não foi adequadamente resolvido. ${ }^{33}$

Por outro lado, a unificação alemã conduziu a um esplêndido processo de desenvolvimento que a levou a rivalizar economicamente com a Grã-Bretanha, além de colocá-la na disputa pelo império colonial, da qual foi alijada porque, quando de sua unificação, tal império já estava consolidado e completamente dividido.

Fato é que, por uma multiplicidade de fatores que inclui os dois processos acima descritos, eclodiu o conflito em 1914, com duração de quatro anos. A guerra devastou a Europa inteira, independentemente de se encontrar o país no lado vencedor ou no vencido, até porque a vitória da Alemanha esteve muito próxima, o que só não ocorreu em função da curta e decisiva participação dos Estados Unidos a partir de 1917.

A guerra encerrou-se com uma série de tratados, assinados individualmente pelos países vencidos com as potências vencedoras, embora tenha ficado conhecido apenas aquele celebrado com a Alemanha, o Tratado de Versalhes, em 1919. O Tratado de Versalhes é importante para nosso tema por dois motivos. Em primeiro lugar, porque ele agravou as já desastrosas consequências financeiras da guerra, impondo um sistema de reparações e cobrança das dívidas contraídas durante o conflito, que, de tão substanciais, fizeram os Estados Unidos passar de devedor internacional, em 1914, a credor, em 1918.

Depois, é no documento em questão que é constituída a Organização Internacional do Trabalho - OIT, a origem da proteção social organizada em escala mundial, girando em torno da questão do trabalho.

A inclusão da OIT no Tratado de Versalhes é consequência de uma incômoda sensação, existente ao final da guerra, de que o liberalismo econômico desenfreado era insustentável. Evidentemente, essa constatação não era decorrente de uma preocupação com o bem-estar dos trabalhadores, como parece sugerir um de seus primeiros antecedentes, a encíclica Rerum novarum, do Papa Leão XIII, de 15 de maio de 1891.

32 MARX, Karl. Manuscritos econômico-filosóficos. São Paulo: Martin Claret, 2005. p. 50-52.

33 Exemplo anedótico da persistência desse sentimento está no fato de que a raça canina conhecida no Brasil pelo nome de "pastor alemão" é conhecida na França pelo nome de "pastor alsaciano", por ser proveniente da região da Alsácia, constantemente envolvida nos conflitos territoriais entre os dois países. A Alsácia, desde 1944, pertence à França, mas sua população está até hoje fortemente vinculada à cultura alemã. 
A encíclica Rerum novarum é outro mito a ser questionado. Comumente citada $^{34}$ como documento avançado de incentivo à proteção social e intervencionismo estatal na economia, ${ }^{35}$ uma leitura integral de seus termos revela a existência de passagens surpreendentes para um documento supostamente progressista e preocupado com a situação dos trabalhadores. ${ }^{36}$ Alguns exemplos, nesses dias em que já desapareceu o pânico da ameaça comunista, parecem até um tanto quanto jocosos:

Os socialistas, para curar este mal, instigam nos pobres o ódio invejoso contra os que possuem, e pretendem que toda a propriedade de bens particulares deve ser suprimida, que os bens dum indivíduo qualquer devem ser comuns a todos, e que a sua administração deve voltar para os Municípios ou para o Estado. (...). Mas semelhante teoria, longe de ser capaz de pôr termo ao conflito, prejudicaria o operário se fosse posta em prática. Outrossim, é sumamente injusta, por violar direitos legítimos dos proprietários, viciar as funções do Estado e tender para a subversão completa do edifício social. $^{37}$

34 O trecho preferido é o seguinte: “Assim, portanto, como, por todos esses meios, o Estado pode tornar-se útil às outras classes, assim também pode melhorar muitíssimo a sorte da classe operária, e isto em todo o rigor do seu direito, e sem ter a temer a censura de ingerência; porque, em virtude mesmo do seu ofício, o Estado deve servir o interesse comum. E é evidente que, quanto mais se multiplicarem as vantagens resultantes dessa ação de ordem geral, tanto menos necessidades haverá de recorrer a outros expedientes para melhorar a condição dos trabalhadores”. LEÃO XIII. Rerum novarum. 12. ed. São Paulo: Paulinas, 2000. p. 34.

35 Como ocorre, por exemplo, em: "Combater a injustiça social, em nome dos ensinamentos evangélicos, foi o objetivo principal das grandes encíclicas papais desde a Rerum Novarum, publicada a 15 de maio de 1891. (...). Inicialmente a Rerum Novarum descreve a situação de infortúnio e miséria imerecida em que vivem os operários, inteiramente ao desamparo desde que no século XVIII as corporações antigas, que eram para eles uma proteção, foram destruídas e não foram substituídas. Critica os ricos e patrões pelo tratamento dispensado aos operários, os quais não devem ser vistos como escravos, mas neles se deve respeitar a dignidade do homem. Estas classes deserdadas encontram seu único suporte nas instituições da Igreja, destinadas a aliviar sua miséria (...). Porém, para esta missão, a Igreja chama o concurso do Estado (...)”.AMADEI, Maria Ignez. Auxílio-doença. 1981. Dissertação (Mestrado) - Faculdade de Direito, Universidade de São Paulo, São Paulo, 1981. p. 16-17.

36 Focaremo-nos, nos exemplos que se seguirão, em demonstrações do pânico do comunismo e em petições de princípio capitalistas transmitidas como verdades incontestáveis, naturais até. Mas não deixa de restar uma sensação de que há, de um modo geral, certo elogio ao Antigo Regime, como o que se nota na seguinte passagem: "O século passado destruiu, sem as substituir por coisa alguma, as corporações antigas, que eram para eles uma proteção; os princípios e o sentimento religioso desapareceram das leis e das instituições públicas, e assim, pouco a pouco, os trabalhadores, isolados e sem defesa, têm-se visto, com o decorrer do tempo, entregues à mercê de senhores desumanos e à cobiça de uma concorrência desenfreada. A usura voraz veio agravar ainda mais o mal". LEÃO XIII. Rerum novarum ... cit., p. 10.

37 Id. Ibid., p. 11. Não se pode deixar de notar que não é apresentada qualquer explicação para a afirmação segundo a qual a implantação prática da teoria socialista prejudicaria os trabalhadores. Outrossim, veja-se o gritante contraste do trecho citado com a seguinte passagem bíblica, que descreve a organização das comunidades cristãs no início de sua diáspora pelo mundo: "Todos os que criam estavam unidos e tinham tudo em comum. Vendiam suas propriedades e os seus bens, e distribuíam o preço por todos, segundo a necessidade que cada um tinha". Atos dos Apóstolos, 2, 44-45. É interessante observar, ainda, que, ao contrário do que sugere a passagem, tal atitude não era voluntária, mas obrigatória para os fiéis. Confira-se 


\begin{abstract}
Mas, e isto parece ainda mais grave, o remédio proposto está em oposição flagrante com a justiça, porque a propriedade particular e pessoal é para o homem, de direito natural. ${ }^{38}$ Mas, além da injustiça de seu sistema, vêem-se bem todas as suas funestas consequências, (...) em lugar dessa igualdade tão sonhada, a igualdade na nudez, na indigência e na miséria. (...). Fique, pois, bem assente que o primeiro fundamento a estabelecer para todos aqueles que querem sinceramente o bem do povo, é a inviolabilidade da propriedade particular. ${ }^{39}$ O primeiro princípio a pôr em evidência, é que o homem deve aceitar com paciência sua condição: é impossível que na sociedade civil todos sejam elevados ao mesmo nível. É, sem dúvida, isto o que desejam os socialistas; mas contra a natureza todos os esforços são vãos. ${ }^{40}$
\end{abstract}

Sem dúvida, seria possível e até fácil reunir outras dezenas de exemplos iguais no curto documento. Mas julgamos que esta amostra já é suficiente para demonstrar que a encíclica em questão é muito mais um libelo anticomunista do que a proposta de uma doutrina social.

Voltando à criação da OIT, a preocupação que inspirou sua criação esteve muito mais ligada à saúde do sistema capitalista ${ }^{41}$ e, principalmente, na mesma linha da encíclica Rerum novarum, ao temor de uma revolução operária, elevado à condição de completo pânico depois que o que parecia inacreditável efetivamente aconteceu, na Rússia, em 1917.

Com efeito, embora houvesse lutas operárias organizadas desde os primórdios do século XIX na Europa, particularmente na Inglaterra e na França, esses movimentos jamais haviam sido devidamente levados a sério, ora esmagados pela força do aparelho de repressão do Estado, ora desmobilizados com migalhas de proteção social demagógica.

Com a vitória da revolução bolchevique em 1917, viu-se que havia a necessidade de se pensar em uma forma mais eficiente de conter a mobilização dos trabalhadores, já que eles passaram a representar perigo real. Paralelamente, iniciou-se a aplicação do conjunto de ideias que ficou conhecido como doutrina do cordão sanitário,

outro trecho, mais adiante: "Um homem, porém, chamado Ananias, de combinação com sua mulher Safira, vendeu um campo, e, com a cumplicidade de sua mulher, reteve parte do preço; e, levando uma parte, pôs aos pés dos apóstolos. (...). Pedro disse: (...) não mentiste aos homens, mas a Deus. Ananias, ao ouvir estas palavras, caiu e expirou. Infundiu-se um grande temor em todos os que ouviram isto". Atos dos Apóstolos, 5, 1-5.

38 Id. Ibid., p. 12.

39 LEÃO XIII. Rerum novarum ... cit., p. 19.

40 Id. Ibid., p. 20.

41 Cf. a respeito HOBSBAWN, Eric John. Era dos extremos: o breve século XX, 1914-1991. São Paulo: Companhia das Letras, 2002. p. 106-107. 
uma tentativa de isolamento da União Soviética, com o objetivo de reduzir as chances de que ela exercesse influência sobre outras partes do mundo.

\section{A Constituição de Weimar}

É importante observar que um processo semelhante ocorreu na Alemanha ao final da guerra, com a promulgação da mítica Constituição de Weimar. Sempre citada como monumento legislativo de criação dos direitos sociais no mundo, a completa omissão acerca do contexto de seu surgimento denuncia que, além de uma imprecisão histórica, ${ }^{42} \mathrm{a}$ eleição da Constituição de Weimar como marco histórico da proteção social ignora, para não dizer que esconde, a função que ela desempenhou no contexto alemão de 1919.

Embora a história seja pouco mencionada, ao menos entre os juristas que se dedicam a estudar os direitos sociais e proferem discurso laudatório à Constituição de Weimar, um fato deve ser enfaticamente lembrado ao se tratar desse assunto: houve uma revolução socialista na Alemanha em 1919, liderada por Karl Liebknecht e Rosa Luxemburgo, a qual, por incrível que pareça, foi sufocada e derrotada pelos assim chamados socialistas moderados.

O contexto dessa curta e malsucedida revolução começa ainda durante a Primeira Guerra Mundial, que criou uma situação de verdadeiro caos social na Alemanha. "O esforço de guerra havia absorvido a tal ponto as menores atividades que acabara por esmagar tudo". ${ }^{43}$ A escassez decorrente do direcionamento da produção industrial para a guerra logo ocasionou o racionamento e, depois, a fome e a ausência de bens de primeira necessidade, inclusive de vestuário, principalmente para a classe operária, já que os ricos podiam abastecer-se no mercado negro. A fome e a desnutrição, por sua vez, aumentavam as chances de contaminação por doenças, registrando-se epidemias de tuberculose, tifo e cólera, por exemplo.

Com esse quadro caótico, o ufanismo nacionalista ${ }^{44}$ que levou a Alemanha à guerra começou a desfazer-se em pouco tempo, rompendo a "aprovação unânime à

42 AConstituição Mexicana de 1917 previu proteção social muito mais ampla e organizada do que a Constituição de Weimar, dois anos antes de sua edição, e em decorrência de um genuíno processo revolucionário popular.

43 RICHARD, Lionel. A república de Weimar (1919-1933). Trad. Jônatas Batista Neto. São Paulo: Companhia das Letras/Círculo do Livro, 1988. p. 14.

44 Vários fatores estão envolvidos no chamado ufanismo nacionalista alemão. O inegável rescaldo do processo de unificação, em que se afirmara uma identidade nacional que, sob o nome de Segundo Reich, fazia uma referência ao Sacro-Império Romano-Germânico, era o principal deles, além de uma intensa propaganda no sentido de que se tratava de uma defesa da nação, de que a Entente havia agredido a Alemanha sem qualquer motivo justificável. Mas havia outros. Julgamos oportuno mencionar, dentre esses, a necessidade de afirmação da "cultura" alemã sobre a "civilização" francesa. Esse dois conceitos foram capitais na formação da nação alemã, que opunha, como característica de seu povo, o fato de o mesmo ser culto, ao fato de o povo francês ser civilizado, querendo com isso significar que o francês praticava um culto à forma 
política imperial e à guerra". ${ }^{45}$ Aos poucos, este descontentamento inicial transformou-se em um vasto movimento de oposição à guerra, a ponto de interferir na política alemã. Anota Richard que, "os partidos propriamente ditos deixaram de contar verdadeiramente. Duas tendências acabaram por surgir. Uma era pela guerra a qualquer custo. A outra, pela paz". 46

Essa divisão da sociedade em duas tendências provocou um fato político muito relevante para o fenômeno de que tratamos. O Partido Social-democrata, integrante da Segunda Internacional e com a significativa representação de cerca de um terço do Parlamento, assistiu o desligamento de parte de seus membros para a fundação de um novo partido, o Partido Socialista Independente, que tinha uma ala radical, de nome Liga Spartakista, liderada por Karl Liebknecht e Rosa Luxemburgo, a qual daria origem, mais tarde, ao Partido Comunista.

Os spartakistas passaram a organizar sua oposição à guerra na forma de greves, em número e volume crescentes, com o objetivo final de estender a revolução bolchevique por toda a Europa. Tais greves, se não tinham força suficiente, até então, para levar a revolução bolchevique à Alemanha, foram aos poucos generalizando um sentimento de necessidade de maior democratização, o que acarretou algumas mudanças, principalmente no que tange à libertação dos líderes socialistas - Karl Liebknecht e Rosa Luxemburgo estiveram presos durante certo período - e aos poderes do corpo legislativo, a ponto de poder caracterizar a Alemanha, a partir de algumas mudanças introduzidas em outubro de 1918, como uma monarquia parlamentar.

As modificações constitucionais não foram suficientemente tempestivas para aplacar os ânimos cada vez mais exaltados. Poucos dias depois, em 3 de novembro, estourou uma revolta no porto de Kiel, com sua tomada pelos marujos, no que logo foram seguidos nas fábricas, pelos operários. Os grevistas formaram um conselho de operários e atuavam sob uma bandeira vermelha.

O mesmo processo deu-se em Stuttgart e Hamburgo. O governo, de que participavam os majoritários, tentou reprimir a revolução, tendo inclusive cessado as relações diplomáticas com a Rússia soviética. No mesmo dia, a Alemanha capitulava na guerra e assinava um armistício.

Quando chegou a Berlim, ainda sem controle, a revolução seria completada, com a implantação do socialismo na Alemanha. Houve todo um dia de desfiles e

decaída herdada da nobreza arcaica, enquanto o alemão preocupava-se com o conteúdo. Uma brilhante descrição desse processo de diferenciação pode ser encontrada em ELIAS, Norbert. O processo civilizador: uma história dos costumes. Rio de Janeiro: Zahar, 1990. v. 1., especialmente na parte I (p. 23-64), intitulada "Sociogênese da diferença entre kultur e zivilisation no emprego alemão".

45 RICHARD, Lionel. A república de Weimar ... cit., p. 23.

46 Id. Ibid., p. 23-24. 
manifestações, inclusive com a tomada de um jornal de direita, no qual foram emitidas orientações para o povo acerca da continuidade da revolução. Ocorre que, paralelamente, os deputados social-democratas adiantaram-se e, reunidos no Parlamento, proclamaram uma república moderada. Utilizaram-se também de seu jornal para fazer prevalecer seu poder sobre o outro poder, o radical, que se anunciava. Lionel Richard destaca como um romance de Wolfgang Koeppen mostra a dualidade existente nesse processo ocorrido na Alemanha:

Sua personagem principal, uma criança, viaja de trem à noite
com sua mãe, da Pomerânia a Berlim. No compartimento,
ela assiste a uma disputa entre dois passageiros. Um
pretende que Liebknecht proclamou a República. O outro
replica com violência que foi Scheidemann. Para justificar
seus argumentos, ambos brandem jornais. Não o mesmo, é
claro. E, cada um à sua maneira, os dois têm razão. ${ }^{47}$

Diversas técnicas foram utilizadas pelos majoritários para esmagar a revolução. A guerra midiática, com a evacuação do jornal tomado pelos revolucionários; a oposição aos conselhos operários, por meio de sindicatos cooptados em negociações com o patronato; e até a violência, já que houve o disparo de tiros contra os manifestantes revolucionários, em algumas ocasiões.

A luta entre majoritários e revolucionários durou cerca de dois meses em Berlim, embora tenha durado um pouco mais na Baviera. Ao final desses seis meses, em janeiro de 1919, Liebknecht e Rosa Luxemburgo foram assassinados em Berlim, a revolução fora contida e os majoritários obtiveram o controle da situação, embora ainda houvesse alguns resquícios de agitação até o final de 1923.

Tão logo restabelecida a "ordem" em Berlim, foram convocadas para 19 de janeiro de 1919 as eleições para a formação de uma assembleia constituinte. Encerrada a votação e apurados os votos, reuniu-se a assembleia, em 6 de fevereiro, na pacata cidade de Weimar, onde estariam isolados de qualquer possibilidade de agitação.

Os comunistas abstiveram-se de apresentar candidaturas e os moderados não conseguiram sozinhos atingir a maioria, como haviam previsto. Assim, foram obrigados a firmar aliança com partidos burgueses, a qual conseguiu abarcar setenta e cinco por cento dos votos, de forma que pode conduzir o processo constituinte.

Como se vê, portanto, a Constituição de Weimar nasceu de um compromisso entre a direita burguesa e os socialdemocratas, unidos em torno do objetivo comum de evitar que uma revolução socialista dominasse a Alemanha, o que quase ocorreu.

$\overline{47}$ RICHARD, Lionel. A república de Weimar ... cit., p. 38. 
Entendemos, assim, que a celebrada Constituição de Weimar, se revista por meio da história dialética da luta de classes, não é um monumento aos direitos dos trabalhadores, mas um instrumento de perpetuação da dominação contra uma tentativa de emancipação que quase foi bem-sucedida.

\section{O período entre guerras e a formação do Estado de bem-estar social}

Além da Primeira Guerra Mundial, o início do século XX apresentou ao capitalismo outro problema que ainda lhe era desconhecido: o desemprego em massa. Não só as economias capitalistas não estavam preparadas para enfrentá-lo como os Estados que as sustentavam, apesar de toda a celebração das leis sociais até então existentes, não conseguiam lidar com a massa de cidadãos atingida por esse problema econômico, mostrando que ainda inexistia proteção social efetiva na Europa e, agora, num novo ator que ganhou relevância no cenário internacional e que passara, com o conflito mundial, a ter a proeminência do capitalismo ocidental: os Estados Unidos da América. Confira-se o impactante texto de Eric Hobsbawm a respeito:

O que tornava a situação mais dramática era que a previdência pública na forma de seguro social, inclusive auxílio-desemprego, ou não existia, como nos EUA, ou, pelos padrões de fins do século XX, era parca, sobretudo para os desempregados a longo prazo. É por isso que a Seguridade Social sempre foi uma preocupação tão vital dos trabalhadores: proteção contra as terríveis incertezas do desemprego (isto é, salários), doença ou acidente, e as terríveis certezas de uma velhice sem ganhos. É por isso que os trabalhadores sonhavam em ver os filhos em empregos de salários modestos, mas seguros, e com aposentadoria. Mesmo no país mais coberto por planos de segurodesemprego antes da Depressão (Grã-Bretanha), menos de $60 \%$ da força de trabalho estava protegida por eles - e isso apenas porque a Grã-Bretanha desde 1920 tinha sido obrigada a adaptar-se ao desemprego em massa. Nas demais partes da Europa (com exceção da Alemanha, onde era acima de $40 \%$ ), a proporção de trabalhadores com direito ao auxílio-desemprego ia de zero a cerca de um quarto. ${ }^{48}$

O capitalismo liberal sofreu, dez anos mais tarde, outro duro golpe: a crise estrutural mundial de proporções gigantescas que teve como estopim a quebra da bolsa de valores de Nova Iorque em 1929, e que ficou conhecida na história pelo nome de Grande Depressão.

48 HOBSBAWM, Eric. A era dos extremos ... cit., p. 97-98. 
Para a ciência econômica atual, as explicações acerca da crise são quase pueris, e decorrem, basicamente, da recusa em flexibilizar o liberalismo econômico. A consequência de sua manutenção pelos onze anos que intermediaram o final da guerra e a quebra da bolsa foi um aumento sem precedentes da concentração de renda, decorrente de recordes sucessivos de produção que não eram refletidos nos salários, os quais ficaram estagnados por todo o período. A despeito disso, os investidores, cegos para a realidade dos trabalhadores e entusiasmados pelos bons desempenhos das indústrias, iniciaram um processo de especulação na bolsa de valores.

Os limites da especulação existiam, e só precisavam de uma ocasião para serem revelados. Com o achatamento do mercado interno em função dos baixos salários e a retração do mercado externo motivada pela devastação causada pela guerra, não havia demanda para a grande oferta de produtos advinda da crescente produção industrial. No dia 24 de outubro de 1929, quando um grande lote de ações não encontrou comprador, os investidores ficaram preocupados e passaram a tentar vender a qualquer preço suas ações. Nesse dia milhares de empresas faliram e milhões de trabalhadores juntaram-se à massa de desempregados.

\begin{abstract}
Para aqueles que, por definição, não tinham controle ou acesso aos meios de produção (a menos que pudessem voltar para uma família camponesa do interior), ou seja, os homens e mulheres contratados por salários, a consequência básica da Depressão foi o desemprego em escala inimaginável e sem precedentes, e por mais tempo do que qualquer um já experimentara. (...). Não houve nada semelhante a essa catástrofe econômica na vida dos trabalhadores até onde qualquer um pudesse lembrar. ${ }^{49}$
\end{abstract}

Também são simples as explicações para o alastramento da crise americana para todo o mundo. Em primeiro lugar, a economia americana era uma grande importadora, de modo que a crise restringiu o mercado para a exportação de produtos de diversos países, entre os quais o Brasil.

Depois, já nessa época havia muito capital americano investido em outros países. Esse dinheiro retornou imediatamente aos Estados Unidos quando estourou a crise, o que também contribuiu para seu alastramento ao restante do mundo capitalista.

Para lidar com a crise de 1929 parecia óbvio que não seria possível insistir no liberalismo selvagem que dominava o capitalismo desde que fora proposto por Adam Smith. Por isso, o presidente americano Franklin Delano Roosevelt adotou, a partir de 1933, as medidas sociais que receberam o nome de New Deal, e que depois foram

49 HOBSBAWM, Eric. A era dos extremos ... cit., p. 97. 
aplicadas também em toda a Europa. Alguns anos depois, coube ao economista inglês John Maynard Keynes sistematizar teoricamente tais medidas.

Keynes, assim como a Constituição de Weimar, é um mito entre os estudiosos dos direitos sociais, exaltado como gênio humanitário que idealizou o welfare state, traduzido no Brasil como Estado de bem-estar social. Também aqui são necessárias algumas precisões. John Keynes era um economista capitalista, que não tinha nenhum apreço particular por trabalhadores ou por sua proteção social. Ele também não planejou a implantação de nenhum Estado de bem-estar, termo que, aliás, passou a ser usado somente em 1940, apenas seis anos antes de sua morte. Sua teoria estava em pleno desenvolvimento ao mesmo tempo em que começou a ser aplicada, e sua obra definitiva, "Teoria geral do emprego, juro e moeda", foi publicada pela primeira vez somente em 1936, três anos após o início do New Deal de Roosevelt.

$\mathrm{O}$ que Keynes pretendia era defender o capitalismo de dois graves e iminentes riscos. Em primeiro lugar, Keynes visava a garantir que o capitalismo estivesse a salvo de sua inviabilidade estrutural. Para isso, imaginou um sistema de geração de demanda interna para absorver os crescentes ganhos de produtividade que, por envolver a questão do emprego e da renda, exigia a presença do trabalhador. Sua teoria, nesse ponto, baseava-se na constatação simples, mas de que não foram capazes os capitalistas até então, de que era necessário que a produção fosse consumida e, para isso, havia a necessidade de que houvesse indivíduos com renda para tanto. Por isso, sua teoria englobava a política de pleno emprego, para o que foram criados alguns mecanismos econômicos que incluíam o aumento dos gastos públicos.

O segundo objetivo era o afastamento do risco de agitações sociais, temor constante a partir da eclosão da revolução russa, principalmente nos momentos de deterioração das condições sociais da classe trabalhadora, como o que estava ocorrendo no mundo então. Coincidentemente, também para isso a eliminação do desemprego era fundamental, o que reforçou as razões para sua adoção como tentativa de solucionar a crise econômica.

Quanto aos trabalhadores, após a guerra o "pleno emprego", ou seja, a eliminação do desemprego em massa, tornouse a pedra fundamental da política econômica nos países de capitalismo democrático reformado, cujo mais famoso profeta e pioneiro, embora não o único, foi o economista britânico John Maynard Keynes (1883-1946). O argumento keynesiano em favor dos benefícios da eliminação permanente do desemprego em massa era tão econômico quanto político. Os keynesianos afirmavam, corretamente, que a demanda a ser gerada pela renda de trabalhadores com pleno emprego teria o mais estimulante efeito nas economias em recessão. Apesar disso, o motivo pelo qual esse meio de aumentar a demanda recebeu tão urgente prioridade -0 
governo britânico empenhou-se nele mesmo antes do fim da Segunda Guerra Mundial - foi que se acreditava que o desemprego em massa era política e socialmente explosivo, como de fato mostrara ser durante a Depressão. ${ }^{50}$

O sucesso das medidas interventivas, aliado ao sempre presente pânico comunista, levou os Estados a, timidamente, principiarem a adoção de algumas políticas sociais, como um reforço ao pleno emprego na tarefa de prevenir as agitações sociais, além de auxiliar na injeção de dinheiro na economia, por meio de gastos estatais e da ampliação da renda de alguns setores alijados do mercado de trabalho.

Isso se deveu, em grande parte, a outra medida profilática tomada durante, depois e em consequência da Grande Depressão: a instalação de modernos sistemas previdenciários. Como surpreender-se por terem os EUA aprovado a Lei de Seguridade Social em 1935? Estamos de tal modo acostumados à predominância de abrangentes sistemas de bem-estar nos Estados desenvolvidos do capitalismo industrial - com algumas exceções, como o Japão, Suíça e EUA - que esquecemos como havia poucos "Estados do Bem-estar" no sentido moderno antes da Segunda Guerra Mundial. Mesmo os países escandinavos apenas começavam a desenvolvê-los. Na verdade, nem o termo Estado do Bem-estar (welfare state) havia entrado em uso antes da década de $40 .{ }^{51}$

Retomando, assim, nossas ponderações sobre Keynes e o Estado de bemestar social, observamos que não só Keynes tinha por objetivo a salvação do capitalismo, como a noção de bem-estar foi objeto de elaboração teórica posterior à obra de Keynes, visto que não integrava, a não ser enquanto parte de seu plano de socorro ao capitalismo, suas preocupações mais imediatas.

Esse fenômeno foi percebido por Paulo Márcio Cruz, que reconstituiu a construção do conceito de Estado de bem-estar social:

O fato de o uso do conceito de Estado de Bem-estar ter origem acadêmica constituiu-se numa razão a mais para se prestar uma atenção especial às primeiras manifestações de concretização política da dimensão social do Estado. ${ }^{52}$

\footnotetext{
50 HOBSBAWM, Eric. A era dos extremos ... cit., p. 99-100.

51 HOBSBAWM, Eric. A era dos extremos ... cit., p. 100.

52 CRUZ, Paulo Márcio. Fundamentos históricos, políticos e jurídicos da seguridade social. In: ROCHA, Daniel Machado da; SAVARIS, José Antonio. Curso de especialização em direito previdenciário. Curitiba: Juruá, 2007. p. 33.
} 
O mesmo Paulo Márcio Cruz havia também notado que não havia um progressismo social central nas políticas de Keynes e na forma de sua adoção prática pelos Estados capitalistas:

Em primeiro lugar, as propostas do Estado de Bem-estar tiveram como intenção garantir a acumulação capitalista mediante a intervenção sobre a demanda - com a intenção de manter a estabilidade social. ${ }^{53}$

Essa tendência foi acompanhada também, por óbvio, de um aumento da carga tributária nestes países. As elites, diante da ameaça real do comunismo instalado na extinta União Soviética, principalmente após a Segunda Guerra Mundial, quando aquele regime ganhou força tecnológica e bélica, resolveram pagar esta conta. Que não foi pequena, mas que valeu a pena, em todos os casos, para aquelas elites. Foi mais ou menos no sentido do "entregar os anéis para não perder os dedos". ${ }^{54}$

Fato é que, a partir da maior intervenção estatal na economia, iniciada após a Grande Depressão, a emergência de políticas sociais, principalmente relacionadas ao trabalho e à previdência social, e a elaboração teórica acerca do Estado de bem-estar social influenciaram-se reciprocamente em um crescente. Ainda assim, e a despeito de o seguro social obrigatório estar presente em diversas nações desenvolvidas, a proteção social não havia, até então, sido tratada de forma sistemática e organizada.

Dez anos depois da crise de 1929, a história voltou a assistir um conflito de proporções mundiais, que envolveu mais países e causou mais destruição do que o primeiro. Sua origem está ligada à luta do mundo democrático contra a ascensão de outra proposta de solução para os problemas colocados pelo liberalismo: as diversas formas de fascismo.

Se o comunismo representava uma ameaça à esquerda do liberalismo, pregando a revolução operária e a abolição da propriedade privada dos meios de produção, o fascismo representava uma ameaça à direita do liberalismo, com suas pretensões totalitárias e restritivas da liberdade e até da vida de determinados grupos.

\section{O plano Beveridge}

Como já dito, a Segunda Guerra Mundial provocou destruição maior que a primeira, e novamente atingiu de forma mais dura a Europa. Fez-se necessária uma nova

\footnotetext{
$53 \quad$ Id. Ibid., p. 26.
}

54 Id. Ibid., p. 28. 
reconstrução do continente, dessa vez fundada em novas bases. É nesse contexto que se encontra o surgimento da seguridade social na forma como a conhecemos hoje. ${ }^{55}$

O presidente americano e o primeiro-ministro britânico, chocados com os horrores do nazismo, pretendiam que a reconstrução do mundo no pós-guerra fosse feita em bases humanitárias, o que, evidentemente, significava uma saída para a garantia da ordem social e da propriedade sem o risco de saídas totalitárias ou comunistas e, consequentemente, pressupunha e garantia a preservação do capitalismo, e passaram a preocupar-se com esse assunto mesmo antes do término do conflito. Com esse pensamento,

Em 14 de agosto de 1941, o presidente dos Estados Unidos, Roosevelt, e o primeiro-ministro britânico, Winston Churchill, firmaram a chamada Carta do Atlântico, formada de uma série de declarações, dentre as quais, na quinta e na sexta, acenou-se para a segurança social e a garantia de os homens viverem "livres do medo e da necessidade". ${ }^{56}$

Com esse pensamento em mente, Churchill nomeou o economista liberal William Beveridge para planejar a reconstrução social da Inglaterra. Beveridge formulou um plano que, conquanto, uma vez mais, mantivesse e assegurasse o capitalismo, propunha intervenções estatais bastante ousadas em questões sociais. Seu plano foi publicado em dezembro de 1942 e logo recebeu aclamação popular como a salvação da Inglaterra.

A imprensa popular teria, inclusive, cunhado a seguinte frase para definir o Plano: "from the cradle to the grave" (do berço ao túmulo) - em uma alusão à cobertura de todas as necessidades humanas desde o nascimento até a morte. Houve imediato reconhecimento popular de que o Plano era dirigido a uma Inglaterra mais igualitária, sendo que Beveridge, rapidamente, teria visto sua popularidade crescer. $^{57}$

O plano Beveridge, efetivamente, pode ser considerado o máximo de concessão aos trabalhadores que seria tolerado sem o sacrifício do sistema capitalista, não faltando quem sustente que se trata de um plano de transição ao socialismo, como o próprio primeiro-ministro trabalhista Clement Attlee, que sucedeu a Churchill. ${ }^{58}$

\footnotetext{
55 "Compreendida em sua inteireza, e não como uma ou outra norma esparsa a respeito do tema, a Seguridade Social somente teve uma primeira normatização orgânica com a implantação do Plano Beveridge, que será minuciosamente estudado mais adiante". CORREIA, Marcus Orione Gonçalves; CORREIA, Érica Paula Barcha. Curso de direito da seguridade social ... cit., p. 1.

56 Id. Ibid., p. 7.

57 CORREIA, Marcus Orione Gonçalves; CORREIA, Érica Paula Barcha. Curso de direito da seguridade social ... cit., p. 9 .

58 Id. Ibid., p. 10.
} 
Beveridge elegeu o que considerou os cinco principais problemas a merecer atenção na Inglaterra: necessidade, doença, ignorância, carência e desemprego. Para enfrentá-los, sugeriu políticas integradas de consistente atuação estatal, com base em seis princípios: benefícios adequados, benefícios cujos valores fossem divididos de forma justa, contribuições em quotas justas, unificação da responsabilidade administrativa, acobertamento das necessidades básicas da população e classificação das necessidades.

Prova da ousadia do plano Beveridge foi sua rejeição pelo governo liberal de Churchill, que apresentou e implementou um plano alternativo chamado White Paper Chase, do qual constavam iniciativas tênues de atuação em algumas das áreas que foram objeto do plano Beveridge.

Com a substituição do governo de Churchill pelo de Attlee, os trabalhistas encontraram no plano Beveridge terreno fértil para a implementação de reformas sociais, e ele acabou sendo integralmente implementado na Inglaterra.

É estranho que Beveridge, um liberal como se autodenominava, após realizar um Plano extremamente social, tivera este rejeitado exatamente pelos liberais (Partido Conservador e Churchill). Mais estranho ainda é que pouco após, entre 1944 e 1949, com a ascendência de um governo trabalhista ao poder, tenha esse liberal tido o seu plano implementado.

(...).

Percebe-se que, a despeito de talhado por um liberal para liberais, o Plano acabou por ser utilizado por socialistas rumo ao socialismo. $\mathrm{Na}$ origem, portanto, a Previdência social se adequava perfeitamente ao Estado Socialista, sendo que o Welfare State se apoderou da ideia, adaptando-a às suas necessidades. ${ }^{59}$

9. Desenvolvimento e ruína do Estado de bem-estar social - para uma tentativa de conclusão

O Estado de bem-estar social funcionou adequadamente por pouco mais de três décadas, proporcionando a completa reestruturação do sistema capitalista e a retomada do crescimento econômico. Seu funcionamento estava assentado sobre a associação entre o Estado interventor e a indústria fordista, ${ }^{60} \mathrm{o}$ que, revelou-se mais tarde,

59 CORREIA, Marcus Orione Gonçalves; CORREIA, Érica Paula Barcha. Curso de direito da seguridade social ... cit., p. 10.

${ }^{60} \mathrm{O}$ termo fordismo indica a indústria organizada em linhas de produção de forma semelhante à que foi idealizada por Henry Ford em sua fábrica de automóveis, no início do século XX. Consiste em aliar a produção em massa de produtos homogêneos com a extrema divisão do trabalho, com absoluto controle de 
estava condicionado à crescente aceleração do consumo e das taxas de crescimento da produtividade.

O modelo demonstrou sua inviabilidade diante da crise em que a economia capitalista mundial entrou a partir da década de 1970, motivada por diversos fatores. Entre os principais fatores da crise estão o choque do petróleo, o fim do padrão de equivalência dólar-ouro, a redução das taxas de crescimento e produtividade, que causou a elevação dos deficit públicos e a saturação do mercado de consumo de produtos industrializados.

A solução para a crise foi formulada tanto em termos econômicos como políticos. Economicamente, passou a prevalecer o modelo japonês de produção industrial, chamado de toyotismo, baseado na produção flexível de bens altamente diferenciados, e na inexistência de estoques, amparada no sistema de logística, permitido pela modernização dos sistemas de comunicação e transporte, denominado just in time. Além disso, o capitalismo cada vez mais deixava sua face industrial para assumir a configuração de capitalismo financeiro, processo altamente intensificado quando, após os choques do petróleo, as taxas de juros passaram a ser utilizadas para atrair investimentos dos países produtores desse material, que estavam com grande concentração monetária.

O capitalismo financeiro não é capaz de manter as políticas de emprego e distribuição de renda, o que reflete diretamente no consumo. Aumentam drasticamente os níveis de desemprego e os investimentos produtivos. A produção industrial passa a prescindir do tamanho do mercado consumidor, substituindo o consumo de massa pelo consumo massivo de uma pequena parcela da população, através da geração de necessidades fictícias por meio da publicidade e da estética.

Em termos políticos, a partir dos governos de Ronald Reagan, nos Estados Unidos, e Margareth Thatcher, na Inglaterra, adotou-se uma agenda, conhecida como neoliberalismo, de diminuição de gastos e políticas sociais, desregulamentação da economia e de política deflacionista, o que supostamente permitiria a retomada do crescimento econômico, porque permitiria a desoneração do investimento produtivo, já que o menor volume de gastos possibilitaria uma menor arrecadação tributária. $\mathrm{O}$ desemprego crescente e a precarização das relações de trabalho serviram para evitar as tensões sociais, ao invés da política anterior de concessão de direitos sociais para tanto.

O neoliberalismo foi bem-sucedido em estabilizar as economias, mas um claro fracasso na sua promessa de crescimento. O retorno do bem-estar gerado pelas forças de mercado não ocorreu; pelo contrário, as desigualdades

tempo de cada operação para impedir atrasos na produção, pelo lado da produção; com o pleno emprego e o consumo em massa, pelo lado do consumo. Cf., a respeito, PRADO, Antônio. A controvérsia da crise do fordismo e a transição pós-fordista: algumas reflexões sobre o caso brasileiro. In: DIEESE. Emprego e desenvolvimento tecnológico: processos de integração regional. São Paulo: DIEESE, 1999. p. 15-28. 
aprofundaram-se em todos os países desenvolvidos. A rede de segurança do mundo do trabalho foi desmantelada: os empregos tornaram-se crescentemente precários; os salários estagnaram; o desemprego decolou; o contrato coletivo vem sendo substituído por contratos individuais e fragmentados; os sindicatos perderam sua força e a capacidade de moderar as tendências mais perversas do capitalismo. O Welfare State foi deformado por políticas sociais seletivas, apesar de ter sobrevivido nas sociedades que mais resistiram ao seu desmantelamento pleno. ${ }^{61}$

Bastou a necessidade, determinada pela crise, associada à existência de meios mais eficientes e baratos de controle de reivindicações sociais, para que todas as garantias fossem retiradas, algumas vezes até mesmo sendo substituídas por políticas de criminalização da pobreza. ${ }^{62}$

Encerrando, assim, estas reflexões históricas críticas, é preciso observar que, com a crise do neoliberalismo evidenciada a partir de 2008, com a chamada crise das hipotecas da economia norte-americana, vemo-nos diante da necessidade de compreender os processos de reorganização da economia para observar de que modo as políticas de proteção social serão rearticuladas após a falência política do neoliberalismo que necessariamente deve se seguir a esta nova crise mundial.

São Paulo, 29 de abril de 2016.

\section{Referências}

AMADEI, Maria Ignez. Auxílio-doença. 1981. Dissertação (Mestrado) - Faculdade de Direito, Universidade de São Paulo, São Paulo, 1981.

COMTE, Auguste. Curso de filosofia positiva. 2. ed. São Paulo: Abril Cultural, 1983.

CORREIA, Marcus Orione Gonçalves; CORREIA, Érica Paula Barcha. Curso de direito da seguridade social. 2. ed. São Paulo: Editora Saraiva, 2002.

CRUZ, Paulo Márcio. Fundamentos históricos, políticos e jurídicos da seguridade social. In: ROCHA, Daniel Machado da; SAVARIS, José Antonio. Curso de especialização em direito previdenciário. Curitiba: Juruá, 2007.

${ }_{61}$ PRADO, Antônio. A controvérsia da crise do fordismo e a transição pós-fordista ... cit., p. 25.

62 O processo, chocante e extremamente perverso, de transferência dos gastos sociais para gastos com presídios privados, em favorecimento ao capital, é descrito, com fartura de dados, em WACQUANT, Loïc. Punir os pobres: a nova gestão da miséria nos Estados Unidos. Rio de Janeiro: Instituto Carioca de Criminologia Freitas Bastos, 2001. 
ELIAS, Norbert. O processo civilizador: uma história dos costumes. Rio de Janeiro: Zahar, 1990. v. 1 .

ENGELS, Friedrich. Prefacio a la situación de la clase obrera en Inglaterra. In: MARX, Karl; ENGELS, Friedrich. Obras escogidas. Moscou: Editorial Progreso, 1955. t. 2.

FERNANDES, Anníbal. Problemas cruciais da previdência social urbana. Mimeografado, 1978, p. 7 apud ALVIM, Ruy Carlos Machado. Uma história crítica da legislação previdenciária brasileira. Revista de Direito do Trabalho, São Paulo, v. 4, n. 18, p. 9-44, março-abril de 1979.

GODOY, Arnaldo Moraes. Historiografia jurídica e direito previdenciário. Revista da Procuradoria Federal Especializada do INSS, Brasília, v. 9, n. 3, out.-dez. 2002. p. 73-80. Disponível em: <http:// www.ieprev.com.br/arq/RPFE9302.pdf>.

HOBSBAWN, Eric John. Era dos extremos: o breve século XX, 1914-1991. São Paulo: Companhia das Letras, 2002.

HUBERMAN, Leo. História da riqueza do homem. 21. ed. rev. Rio de Janeiro: Editora Guanabara, 1986.

LEÃO XIII. Rerum novarum. 12. ed. São Paulo: Paulinas, 2000.

LÖWY, Michael. As aventuras de Karl Marx contra o Barão de Münchhausen. Marxismo e positivismo na sociologia do conhecimento. 8. ed. São Paulo: Cortez, 2003.

MARX, Karl. Manuscritos econômico-filosóficos. São Paulo: Martin Claret, 2005. . O capital. São Paulo: Boitempo, 2014. v. 1.

; ENGELS, Friedrich. Manifesto comunista. São Paulo: Boitempo, 1998.

; ENGELS, Friedrich. A ideologia alemã. São Paulo: Boitempo, 2007.

MELLO, Leonel Itaussu Almeida; COSTA, Luís César Amad. História moderna e contemporânea. 5. ed. São Paulo: Scipione, 1999.

OLIVEIRA, Luciano. Não fale do Código de Hamurábi!: a pesquisa sócio-jurídica na pós-graduação em direito. Disponível em: <https://www.uniceub.br/media/180293/Texto_IX.pdf>. Acesso em: 29 abr. 2016.

PRADO, Antônio. A controvérsia da crise do fordismo e a transição pós-fordista: algumas reflexões sobre o caso brasileiro. In: DIEESE. Emprego e desenvolvimento tecnológico: processos de integração regional. São Paulo: DIEESE, 1999.

RICHARD, Lionel. A república de Weimar (1919-1933). Trad. Jônatas Batista Neto. São Paulo: Companhia das Letras/Círculo do Livro, 1988.

WACQUANT, Loïc. Punir os pobres: a nova gestão da miséria nos Estados Unidos. Rio de Janeiro: Instituto Carioca de Criminologia Freitas Bastos, 2001. 
WEBER, Max. Aética protestante e o espírito do capitalismo. In: WEBER, Max. Textos selecionados. São Paulo: Abril Cultural, 1980.

. Parlamentarismo e governo numa Alemanha reconstruída. In: WEBER, Max. Textos selecionados. São Paulo: Abril Cultural, 1980. 